\title{
AMPK $\gamma$ is Required for Maintaining Epithelial Cell Structure and Polarity Hyongjong Koh*
}

Department of Pharmacology, Mitochondria Hub Regulation Center (MHRC), Dong-A University College of Medicine, Busan 602-714, Korea Received January 27, 2011 /Accepted February 9, 2011

\begin{abstract}
AMP-activated protein kinase (AMPK), a heterotrimeric complex comprising a catalytic a subunit and regulatory $\beta$ and $\gamma$ subunits, has been primarily studied as a major metabolic regulator in various organisms, but recent genetic studies discover its novel physiological functions. The first animal model with no functional AMPK $\gamma$ subunit gene was generated by using Drosophila genetics. AMPK $\gamma$ null flies demonstrated lethality with severe defects in cuticle formation. Further histological analysis found that deletion of $A M P K \gamma$ causes severe defects in cell polarity in embryo epithelia. The phosphorylation of nonmuscle myosin regulatory light chain (MRLC), a critical regulator of epithelial cell polarity, was also diminished in $A M P K \gamma$ null embryo epithelia. These defects in AMPK $\gamma$ mutant epithelia were successfully restored by over-expression of $A M P K \gamma$. Collectively, these results suggested that AMPK $\gamma$ is a critical cell polarity regulator in metazoan development.
\end{abstract}

Key words : Drosophila, AMPK $\gamma$, MRLC, epithelia, cell polarity

\section{Introduction}

AMP-activated protein kinase (AMPK), a heterotrimeric complex comprising a catalytic a subunit and regulatory $\beta$ and $\gamma$ subunits, is well conserved from yeast (Saccharomyces cerevisiae), worm (Caenorhabditis elegans) and fruit fly (Drosophila) to human $[2,6,8]$. During metabolic stress, when cellular AMP:ATP ratios rise, AMPK senses increased AMP level with its cystathionine beta-synthase (CBS) domains in its regulatory $\gamma$ subunit and is activated by phosphorylation of Thr172 in the activation loop of its catalytic a subunit $[2,6,8]$. This activated AMPK down-regulates ATP-consuming anabolic pathways, and up-regulates ATP-generating catabolic pathways to maintain energy homeostasis in the cell $[2,6,8]$. Although the biochemical characteristics of AMPK were extensively studied by cell line-based studies, there were few genetic data on in vivo function of metazoan AMPK, due to the existence of multiple AMPK subunit isoforms encoded by different genes [8]. Because Drosophila has no redundancy in AMPK subunit genes [13], AMPK signaling was successfully nullified in the Drosophila system [10,12]. All AMPK a-null mutant flies are lethal and fail to develop to adulthood even in the presence of sufficient nutrients [10,12]. Surprisingly, loss of $A M P K a$ induces dis-

*Corresponding author

Tel : +82-51-240-2805, Fax : +82-51-241-0778

E-mail : hjkoh@dau.ac.kr ruption of cell polarity accompanying with disorganized actin cytoskeleton in embryonic and wing epithelial cells $[10,12]$. These abnormalities in epithelial cell polarity are highly similar to those of the mutants of LKB1, the upstream kinase of AMPK [10]. Moreover, constitutive activation of AMPK restores these defects in LKB1-null mutants, demonstrating AMPK as a novel regulator of cell polarity [10]. These genetic studies using Drosophila successfully discovered novel physiological functions of AMPK, and also provide valuable tools to dissect its in vivo signaling mechanisms.

In this report, the first $A M P K \gamma$ null Drosophila mutant was generated and characterized. The deletion of $A M P K \gamma$ induced lethality and the severe defects in cuticle formation. Further analysis showed that $A M P K \gamma$ has an important role in maintaining epithelial cell polarity. These data strongly suggest that $A M P K \gamma$ is critical for in vivo AMPK signaling.

\section{Materials and Methods}

\section{Fly Strains}

The G5100 fly line with a P-element in the AMPK $\gamma$ locus was obtained from GenExel (Taejon, Korea). The deletion mutants were generated from P-element excision experiments. To generate the over-expression lines for $A M P K \gamma$, a HA-tagged entire $A M P K \gamma \quad V$ open reading 
frame was subcloned into pUAST vector. The fly lines for FLP-DFS (autosomal flipase-dominant female sterile) technique and $h s$ GAL4 were obtained from the Bloomington Stock Center (Bloomington, IN, USA).

\section{Production of AMPK $\gamma$ null embryos}

The germ line clones of $A M P K \gamma^{D 39}$ were generated using the autosomal FLP-DFS technique. In detail, 82AFRT AMPK $\gamma{ }^{D 39} /$ TM6B females were crossed with $y w$ $h s \mathrm{FLP} / \mathrm{Y} ; ;$ 82AFRT $\mathrm{P}\left[\mathrm{w}^{+}\right.$, ovo $\left.^{D 1}\right]$ males. Their progeny larvae were heat-shocked for $2 \mathrm{hr}$ at $37^{\circ} \mathrm{C}$ at the first instar larval stage. $y w h$ s-FLP;; 82AFRT P $\left[w^{+}\right.$, ovo $\left.{ }^{D 1}\right] / 82 \mathrm{AFRT} A M P K \gamma$ ${ }^{D 39}$ females (3 day-old) were selected and crossed with AMPK $\gamma^{D 39} /$ TM3 GFP males to obtain AMPK $\gamma^{D 39}$ null embryos. To produce $A M P K \gamma$ null embryos expressing $A M P K \gamma, y w h s$ FLP;; 82AFRT P $\left[w^{+}\right.$, ovo $\left.^{D 1}\right] / 82 \mathrm{AFRT} A M P K$ $\gamma^{D 39}$ females were crossed with hs-Gal4 UAS-AMPK $\gamma$ / CyO Act-GFP, AMPK $\gamma{ }^{D 39} / \mathrm{TM} 3$ GFP males. For expression of $U A S-A M P K \gamma$ in $A M P K \gamma$ null embryos, eggs were collected and aged at $30^{\circ} \mathrm{C}$.

\section{Cuticle preparation}

For the cuticle preparations, embryos were collected and dechorinated as previously described [10]. Dechorinated embryos were immersed in a solution containing acetic acid and glycerol at a $3: 1$ ratio and incubated overnight at $65^{\circ} \mathrm{C}$. Embryos were then mounted in Hoyer's medium and incubated $24 \mathrm{hr}$ at $65^{\circ} \mathrm{C}$.

\section{Immunostaining}

I used anti-phospho MRLC (1:50, Cell Signaling Technology, Danvers, MA, USA), anti-aPKC (1:1,000, Santa Cruz Biotechnology, Santa Cruz, CA, USA), and anti-Discs large (4F3, 1:200, DSHB, Iowa City, IA, USA) antibodies as primary antibodies. Texas red and fluorescein isothiocyanate (FITC)-conjugated secondary antibodies (Molecular Probes, Eugene, OR, USA) were used at a 1:200 dilution. DNA was visualized by DAPI (Sigma, St. Louis, MO, USA). Drosophila tissues were fixed in $4 \%$ formaldehyde for $5 \mathrm{~min}$. After the standard immunostaining procedures [10], tissues were observed with a laser scanning confocal microscope LSM700 (Carl Zeiss, Göttingen, Germany).

\section{Results and Discussion}

Drosophila AMPK $\gamma$ subunit is highly homologous to its mammalian counterparts and Sacharomyces cerevisiae SNF4, especially in its CBS domains [17]. Drosophila has 6 AMPK $\gamma$ subunit isoforms encoded by a single gene (17, Fig. 1), but the null mutant which nullified the expression of all

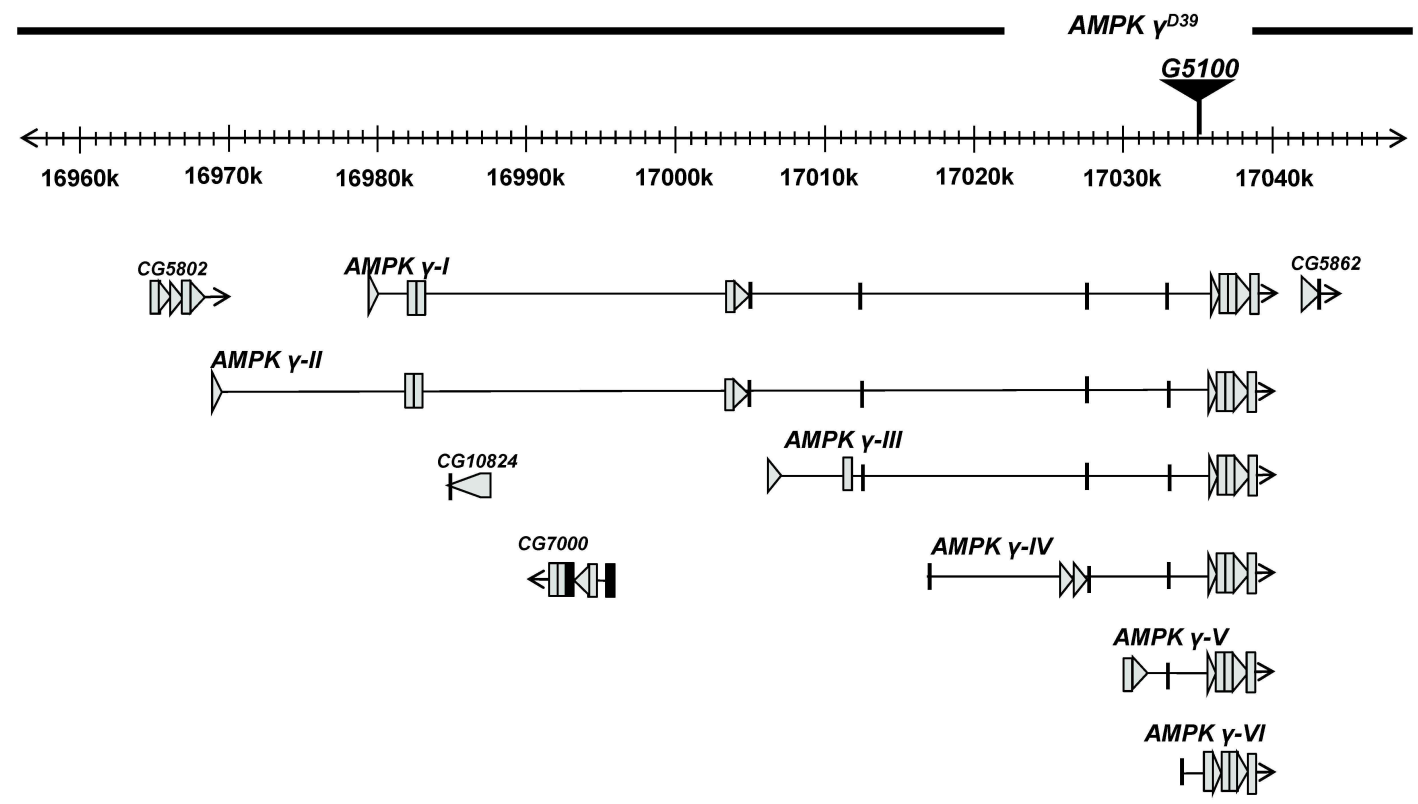

Fig. 1. Genomic map of $A M P K \gamma$. P-element insertion (triangle), exons (rectangles and arrow heads) and introns (lines) are shown. $A M P K \gamma^{D 39}$ contains an about $17 \mathrm{~kb}$ deletion encoding whole CBS domains. 
AMPK $\gamma$ isoforms was not available. From an extensive searching of the GenExel library ( 20,000 independent EP lines), we isolated AMPK $\gamma^{G 5100}$ (G5109), an EP line with a P-element insertion near exons encoding the CBS domains shared by all AMPK $\gamma$ subunit isoforms (Fig. 1). Subsequently, I have generated an AMPK $\gamma$ deficient line, $A M P K \gamma^{D 39}$ by imprecise excision of the P-element from G5100. PCR-based molecular analyses demonstrated that the exons containing the CBS domains were totally deleted in this mutant (Fig. 1). RT-PCR clearly demonstrated that $A M P K \gamma^{D 39}$ is a genuine null allele (data not shown).

This null mutant displayed a larval lethality, demonstrating that $A M P K \gamma$ is essential to complete development. Then, I investigated role of AMPK $\gamma$ in early development by generating germ line clones (GLC) of $A M P K \gamma$ null mutants to eliminate the maternal effect. Interestingly, $A M P K$ $\gamma^{D 39}$ null embryos completely failed to hatch, demonstrating that $A M P K \gamma$ is indispensable for the completion of embryogenesis. Extensive examination of $A M P K \gamma$ mutant embryos revealed almost complete loss of the cuticle structure (Fig. 2).

Because the structure of embryonic cuticle highly reflects the organization of underlying epidermis that secretes it, I supposed that the epithelial cell structures of $A M P K \gamma \mathrm{mu}-$ tant embryos would be also severely impaired. Wild-type Drosophila embryonic epithelia contain two distinct membrane domains-an apically localized cell-cell adhesive junction known as zonula adherens (ZA) and a more basal junctional complex known as septate junction (SJ) [9]. However,
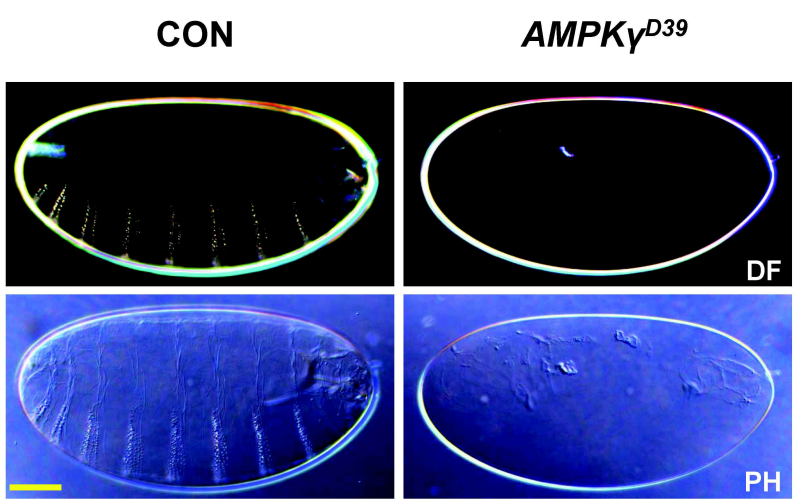

Fig. 2. Cuticle formation defects in $A M P K \gamma$ null embryos. Wild type (Con) and $A M P K \gamma$ null (AMPK $\gamma{ }^{D 39}$ ) embryo cuticles were analyzed by dark field (DF) and phase contrast $(\mathrm{PH})$ microscopy. Yellow scale bar: $50 \mu \mathrm{m}$. in $A M P K \gamma$ mutant embryos, localization of atypical PKC (aPKC), a component of the apical complex which regulates the formation of ZA [9], was found severely disrupted (Fig. 3). Discs-large (Dlg), normally localizing at or below SJ [9], was also mislocalized in AMPK $\gamma$ mutant embryos (Fig. 3). When AMPK $\gamma$ was re-introduced in AMPK $\gamma$ mutants using GAL4-UAS system, the defected epithelial structures and mislocalized polarity determinants were successfully restored (Fig. 3). These results strongly supported that $A M P K$ $\gamma$ is critical for maintaining epithelial structures in Drosophila development.

In previous reports, extensive biochemical and genetic analyses demonstrated that AMPK regulates cell polarity by phosphorylating myosin regulatory light chain (MRLC; also known as MLC2), a critical molecule for cell polarity establishment $[3,7,10,15]$. The regulatory phosphorylation site of MRLC is directly phosphorylated by activated AMPK in vitro and in vivo [10]. After this phosphorylation, MRLC induces the actin cytoskeleton structural change which has a critical role in the regulation of cell polarity [10]. To test the role of $A M P K \gamma$ in in vivo MRLC phosphorylation, $A M P K \gamma$ mutant embryos were stained with phospho-specific MRLC antibodies. Although phosphorylated MRLC was specifically localized to apical region of wild-type epithelia, the deletion of $A M P K \gamma$ almost completely suppressed MRLC phosphorylation (Fig. 4). Moreover, over-expression of $A M P K \gamma$ completely restored MRLC phosphorylation in the AMPK $\gamma$ null epithelia (Fig. 4). Collectively, these data demonstrated that

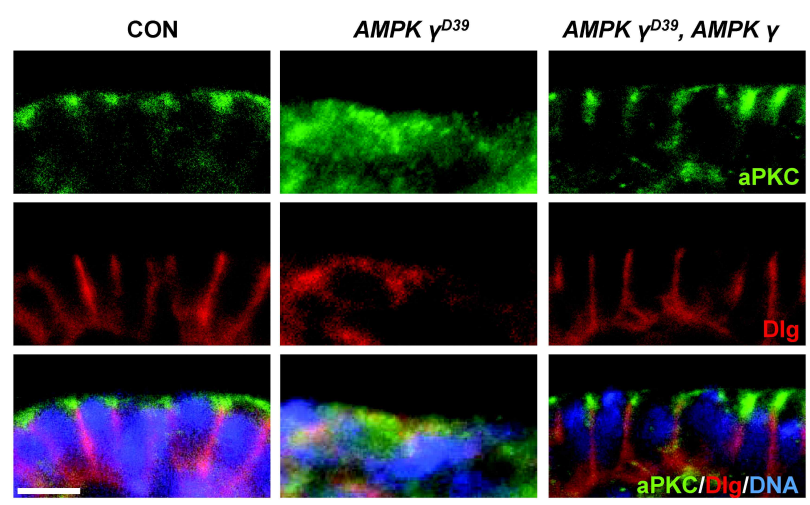

Fig. 3. AMPK $\gamma$ is required for maintaining epithelial cell polarity. Epithelia of wild type (Con), $A M P K \gamma$ null $\left(A M P K \gamma^{D 39}\right)$, and $A M P K \gamma$ null expressing $A M P K$ $\gamma\left(A M P K \gamma^{D 39}, A M P K \gamma\right)$ were stained with anti-aPKC antibody (aPKC, green), anti-Dlg antibody (Dlg, red) and DAPI (DNA, blue). White scale bar: $5 \mu \mathrm{m}$. 


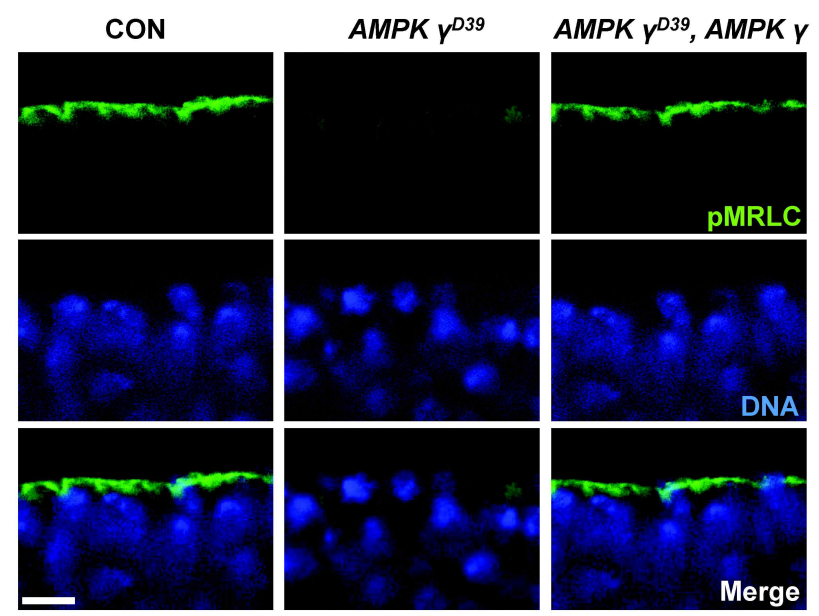

Fig. 4. Loss of MRLC phosphorylation in $A M P K \gamma$ null epithelia. Wild type (Con), $A M P K \gamma$ null $(A M P K \gamma$ D39, and $A M P K \gamma$ null expressing $A M P K \gamma$ (AMPK $\left.{ }^{D 39}, A M P K \gamma\right)$ embryo epithelia were stained with anti-phospho MRLC antibody (pMRLC, green) and DAPI (DNA, blue). White scale bar: $5 \mu \mathrm{m}$.

AMPK $\gamma$ is essential for in vivo MRLC phosphorylation, suggesting the critical role of AMPK $\gamma$ in AMPK-mediated cell polarity regulation.

In genetic analyses during decades, mutations in $A M P K$ $\gamma$ isoforms induce various symptoms in various animals. An autosomal dominant mutation in AMPK $\gamma 3$ induces a dramatic increase in skeletal muscle glycogen content in pigs [11]. After this discovery, several groups identified AMPK $\gamma 2$ gene mutations associated with familial cardiac hypertrophy $[1,5]$. The most patients with these $\gamma 2$ mutations also demonstrated severe defects in electrical conductance, similar to the conduction abnormalities observed in Wolff-Parkinson-White syndrome $[1,5]$. In addition, a deletion of first exon of an AMPK $\gamma$ isoform induced progressive neurodegeneration and neuronal cell death in Drosophila [17]. Because loss of cell polarity is strongly correlated with more aggressive and invasive growth of malignant cells [16], the cell polarity controlling roles of AMPK $\gamma$ suggest that AMPK $\gamma$ mediates the tumor suppressing function. A small scale case study shows that metformin, an AMPK activating anti-diabetic drug, reduces the risk of cancer in diabetic patients [4]. Moreover, metformin suppresses carcinogen-induced cancers in hamsters [14]. These data support the tumor suppressing role of AMPK, and raise the possibility that metformin and other AMPK activating agents can be used for the treatment of AMPK-related cancers. Collectively, the AMPK $\gamma$ mutant and AMPK $\gamma$ transgenic models generated in this study will provide valuable tools and insights into investigating various AMPK $\gamma$-related diseases and abnormalities.

\section{Acknowledgement}

This work was supported by the National Research Foundation of Korea (NRF) grant funded by the Korean government (MEST) (331-2008-1-C00225).

\section{References}

1. Blair, E., C. Redwood, H. Ashrafian, M. Oliveira, J. Broxholme, B. Kerr, A. Salmon, I. Ostman-Smith, and H. Watkins. 2001. Mutations in the g2 subunit of AMP-activated protein kinase cause familial hypertrophic cardiomyopathy: evidence for the central role of energy compromise in disease pathogenesis. Hum Mol. Genet. 10, 1215-1220.

2. Carling, D. 2004. The AMP-activated protein kinase cascade-a unifying system for energy control. Trends Biochem Sci. 29, 18-24.

3. Edwards, K. A. and D. P. Kiehart. 1996. Drosophila nonmuscle myosin II has multiple essential roles in imaginal disc and egg chamber morphogenesis. Development 122, 1499-1511.

4. Evans, J. M., L. A. Donnelly, A. M. Emslie-Smith, D. R. Alessi, and A. D. Morris. 2005. Metformin and reduced risk of cancer in diabetic patients. Br. Med J. 330, 1304-1305.

5. Gollob, M. H., M. S. Green, A. S. Tang, T. Gollob, A. Karibe, A. S. Ali Hassan, F. Ahmad, R. Lozado, G. Shah, Fananapazir, L. L. Bachinski, and R. Roberts. 2001. Identification of a gene responsible for familial Wolff-Parkinson-White syndrome. N. Engl. J. Med 344, 1823-1831.

6. Hardie, D. G., J. W. Scott, D. A. Pan, and E. R. Hudson. 2003. Management of cellular energy by the AMP-activated protein kinase system. FEBS Lett. 546, 113-120.

7. Ivanov, A. I., D. Hunt, M. Utech, A. Nusrat, and C. A. Parkos. 2005. Differential roles for actin polymerization and a myosin II motor in assembly of the epithelial apical junctional complex. Mol. Biol. Cell 16, 2636-2650.

8. Kahn, B. B., T. Alquier, D. Carling, and D. G. Hardie. 2005. AMP-activated protein kinase: ancient energy gauge provides clues to modern understanding of metabolism. Cell Metab. 1, 15-25.

9. Knust, E. and O. Bossinger. 2002. Composition and formation of intercellular junctions in epithelial cells. Science 298, 1955-1959.

10. Lee, J. H., H. Koh, M. Kim, Y. Kim, S. Y. Lee, R. E. Karess, S. H. Lee, M. Shong, J. M. Kim, J. Kim, and J. Chung. 2007. Energy-dependent regulation of cell structure by AMP-acti- 
vated protein kinase. Nature 447, 1017-1020.

11. Milan, D., J. T. Jeon, C. Looft, V. Amarger, A. Robic, M. Thelander, C. Rogel-Gaillard, S. Paul, N. Iannuccelli, L. Rask, H. Ronne, K. Lundström, N. Reinsch, J. Gellin, E. Kalm, P. L. Roy, P. Chardon, and L. Andersson. 2000. A mutation in PRKAG3 associated with excess glycogen content in pig skeletal muscle. Science 288, 1248-1251.

12. Mirouse, V., L. L. Swick, N. Kazgan, D. St Johnston, and J. E. Brenman. 2007. LKB1 and AMPK maintain epithelial cell polarity under energetic stress. J. Cell Biol. 177, 387-392.

13. Pan, D. A. and D. G. Hardie. 2002. A homologue of AMP-activated protein kinase in Drosophila melanogaster is sensitive to AMP and is activated by ATP depletion. Biochem J. 367, 179-186.
14. Schneider, M. B., H. Matsuzaki, J. Haorah, A. Ulrich, J. Standop, X. Z. Ding, T. E. Adrian, and P. M. Pour. 2001. Prevention of pancreatic cancer induction in hamsters by metformin. Gastroenterology 120, 1263-1270.

15. Tan, J. L., S. Ravid, and J. A. Spudich. 1992. Control of nonmuscle myosins by phosphorylation. Annu. Rev. Biochem 61, 721-759.

16. Thiery, J. P. 2002. Epithelial-mesenchymal transitions in tumor progression. Nat. Rev. Cancer 2, 442-454.

17. Tschaepe, J. A., C. Hammerschmied, M. Muhlig-Versen, K. Athenstaedt, G. Daum., and D. Kretzschmar. 2002. The neurodegeneration mutant lochrig interferes with cholesterol homeostasis and APPL processing. EMBO J. 21, 6367-6376.

\section{초록 : AMPK $\gamma$ 유전자의 표피세포극성 유지기능 규명 \\ 고형종* \\ (동아대학교 의과대학 약리학교실)}

AMPK는 catalytic a subunit과 regulatory $\beta$ 및 $\gamma$ subunit으로 구성된 인산화 효소로, 그 동안 생체 내 중요 대사 조절자로써 연구되어 왔으나, 최근 유전학 연구를 통해 지금까지 밝혀지지 아니한 새로운 생체기능을 가짐 이 밝혀졌다. 본 연구에서 초파리 유전학 기법을 활용하여 AMPK $\gamma$ subunit 유전자가 결손된 모델 초파리를 제작 하여 연구한 결과, AMPK $\gamma$ 유전자 결손 시 초파리 embryo의 표피형성이 심각하게 저해됨을 발견하였고, 조직학적 실험을 통해 표피세포의 극성이 AMPK $\gamma$ 유전자 결손 초파리에서 손상되어 있음을 확인하였다. 또한 세포극성을 조절하는 중요 분자인 MRLC의 인산화 또한 AMPK $\gamma$ 유전자 결손 시 저해되었으며, AMPK $\gamma$ 유 전자 재도입 시 MRLC인산화와 표피세포의 극성이 모두 회복됨이 확인되어, 초파리 표피세포의 극성유지에 $\mathrm{AMPK} \gamma$ 유전자가 필수적 임을 확인하였다. 
